\title{
한국 농어업유산제도의 정립방향* \\ Establishment of the Agriculture and Fisheries Heritage System in Korea
}

\author{
윤원근** · 최식인*** \\ Won Keun Yoon-Sik In Choi
}

\section{Abstract}

This study aims to propose the policy direction for agriculture and fisheries heritage system in Korea. The agriculture and fisheries heritage system is defined as traditional agricultural activity systems and landscapes which should be preserved, sustained and handed down and evolved from the co-adaptation of a community with its cultual, agricultural, biological environment.

The key characteristics of the agriculture and fisheries heritage system of Korea are as follows; Firstly, this system designates software and hardware factor of heritage in integrative manner. secondly, this system seeks to preserve and utilize such heritages simultaneously. Thirdly, this system intends to strengthen the role of people in rural area. Fourthly, this system makes use of new engine of growth in agricultural community. This system is designed by comparing and reviewing several related domestic and foreign systems including FAO' GIAHS.

주요어(key words): 농어업유산제도(Agriculture and Fisheries Heritage System)

* 이 논문은 2012년 2월 농업전망2012(한국농촌경제연구원)에서 발표한 '한국 농어 업·농어촌 유산발굴과 보전'(윤원근, 최식인)을 기초로 하여 작성하였다.

***협성대학교 지역개발학과 교수. e-mail: younwk@uhs.ac.kr

*** 협성대학교 지역개발학과 교수. e-mail: sikin@uhs.ac.kr 


\section{1. 서 론}

\section{1. 연구의 필요성과 목적}

이 연구는 한국농어업유산제도의 도입1)과 정립방향을 모색하고자 하 는 것이다. 농촌정책의 패러다임은 변화하고 있다. 역사와 문화를 존중 하고, 생물다양성을 유지하고 보전하는 보전적 시각의 정책이 부각되고 있다.

현시점에서 한국의 농어업 - 농어촌 유산발굴과 보전정책의 도입이 왜 필요한 것인가? 첫째, 농촌발전을 위하여 자원을 활용함에 있어서 개발 중심적, 경제주의적인 관점이 지배함에 따라, 한국의 고유한 전통적이고 가치 있는 농어업 - 농어촌유산이 가치를 인정받지 못한 채 과이용되거나 소멸되어 심각하게 훼손되고 있는 상황에 직면하고 있다. 우리의 고유한 농어업 - 농어촌유산에 어떤 것이 있었는지조차 인식하지 못할 정도로 농 촌공간은 심하게 변화를 겪어왔으며, 이대로 지속되는 경우 우리의 농촌 공간에서 과연 우리의 역사와 전통성을 대표할 수 있는 자원이 어떤 것 이 있는지, 얼마나 남아 있는지조차 모르게 될 것으로 전망되고 있다.

둘째, 농어업 - 농어촌의 유산은 우리가 보호하고 지켜야 할 자산이기 도 하지만, 농어촌의 발전을 위한 새로운 성장 동력이면서, 우리의 국토 공간을 장소적으로 차별화시켜줄 수 있는 하나의 핵심인자라는 면에서 중요성이 부각되고 있다. 한국의 농어업 농어촌의 정체성이 훼손되고, 농어업 - 농어촌의 본질에 해당되는 부분까지도 손상될 경우, 과연 우리 는 무엇을 근거로 새로운 미래창조를 위한 한국적 농어업-농어촌 발전 을 논의할 수 있을 것인가?

1) 농림수산식품부는 2012년 4월에 농어업유산제도를 도입하였으며 현재 지방자차단체 부터 농어업유산을 신청받고 있는 중에 있음. 
셋째, 현재 문화재청, 환경부, 농식품부 등에서 농어업 및 농어촌에 산재하는 일부 문화유산을 보호하기 위한 제도가 운용되고 있으나, 부처 별 필요성에 따라서 부분적으로 접근되고 있어서, 농어업·농어촌의 발 전을 위한 유산보전과 활용이라는 전체적인 시각에서 체계적으로 접근해 야할 필요성이 제기되고 있다.

넷째, 국제식량기구(FAO) 등에서 운용하고 있는 세계농업유산제도 (GIAHS)가 국내의 공공부문이나 민간부문의 활동과 연계되지 못함에 따라, 국제적인 정책 활동이 국내정책과 관련성이 없이 단절되는 상황에 놓여있다. 국제농업기구의 활동에 대하여 국내의 관련부서가 관심을 가 지고, 연계된 정책을 수립하고 실행될 수 있을 때, 글로벌 시대의 흐름에 동참할 수 있고, 뒤떨어지지 않는 방향으로 나아갈 수 있다.

위와 같은 문제제기에 따라 이 연구는 한국의 농촌현장에서 남아있는 전통적이면서 고유한 농어업유산을 체계적으로 발굴하고, 보전과 활용을 통하여 보다 선진화된 농촌공간을 재창조하는 데 기여할 수 있는 제도도 입과 정책방안을 모색하는 데에 연구목적이 있다.

\section{2. 연구 범위 및 방법}

연구범위는 우리나라의 농어업·농어촌유산 중에서 먼저 농어업유산 을 지정하여 보호할 필요성을 제기하고 연구의 범위를 농어업활동과 관 련이 있는 농어업유산제도의 정립으로 국한한다. 농어업유산은 농업활동 과 관련성이 있고 농어촌유산은 농촌주민의 일상생활활동과 관련성이 있 다는 면에서 구분될 수 있다.

연구의 주요방법과 절차는 다음과 같다. 먼저 국내외의 농어업유산관 련 제 개념들을 분석하여 이들 간의 차별성을 규명한 후 상호 간의 관계 를 분명히 한다. 그리고 이로부터 도출된 개념요소에 근거하여 우리나라 
에 적용할 농어업유산의 개념을 제시한다. 다음으로 국내외의 유산관련 제도를 분석하여 시사점을 도출하고 이어서 우리나라 유산제도의 정립을 위한 기본방향의 제시와 제도 정립을 위한 쟁점들을 검토한다.

\section{2. 한국농어업유산의 개념정립}

유산은 과거로부터 전승되어 내려 온 것으로 미래 세대의 편익을 위하 여 물려주어야 하는 자산이다. 유산은 자연유산, 문화유산, 농업유산, 농 촌유산 등으로 분류될 수 있다. 문화유산과 자연유산은 유네스코의 세계 문화유산과 세계자연유산의 지정에서, 그리고 농촌유산은 $\mathrm{EU}$ 의 농촌유 산 가이드에서, 그리고 농업유산은 $\mathrm{FAO}$ 의 세계농업유산제도에서 그 개 념을 찾을 수 있다. 다음에서는 $\mathrm{FAO}$ 의 농업유산개념을 먼저 검토한 후 이를 표준으로 다른 유산개념들과의 차이점이 무엇인지 비교분석한다. 그리고 이를 바탕으로 우리나라의 농어업유산의 개념을 정립한다.

\section{1. $\mathrm{FAO}$ 의 $\mathrm{GIAHS}$ 개념}

FAO에서는 2002년에 세계농업유산제도(GIAHS: globally important agricultural heritage systems)를 창설하였다. 이 제도는 차세대에 계승해야 할 세계적으로 중요한 농업기술과 생물다양성 등을 가진 농업 유산을 보전하는 데 목적이 있다. 농업유산(agricultural heritage)이 란 용어와 그 개념은 이 제도로부터 새롭게 조명되기 시작하였다.

GIAHS란 '지역사회의 지속가능한 발전에 대한 열망과, 환경과의 동 반적응을 통해 생물다양성이 잘 유지되고 있는 토지이용체계와 생태경관 으로 정의된다(www.fao.org/nr/giahs). GIAHS의 정의 속에는 생물 
다양성, 토지이용체계, 경관이라는 핵심 개념요소가 들어 있다.

먼저 생물다양성은 지역사회가 식품의 안전 및 확보를 위한 열망, 그 리고 환경과의 밀접한 관련성을 가지면서 동반적응을 통해 진화해 온 것 이라는 의미를 가진다. 즉 농업유산 개념 속의 생물다양성은 자연 상태 로서의 생물종의 유지라기보다는 인간의 농업 활동과의 관계 속에서 유 지되고 진화해 온 것이며, 이는 지역사회의 발전과 깊은 연관성을 맺고 있다는 점에서 특징이 있다.

토지이용체계는 농업활동과의 관계 속에서 설명할 수 있다. 토지이용 체계의 개념 속에는 고유한 토지 및 수자원 활용기법, 고유한 식량 품종 의 유지를 위한 농법 등과 같은 요소를 포함시킬 수 있다. 그러므로 이 러한 토지이용체계라는 개념요소는 농업유산의 개념이 소프트웨어적 요 소를 포함하고 있음을 분명히 한다.

경관은 위에서 논의한 농업활동이 이루어지고 있는 농업생산지역과 인 접생물서식지를 포괄하는 면(面)적 개념으로 하드웨어적 요소이다.

\section{2. 유네스코의 유산 개념}

유네스코(UNESCO)에 따르면 유산은 크게 자연유산, 문화유산, 복 합유산으로 분류된다. 이 중에서 자연유산(natural heritage)이란 '자 연적으로 형성된 것으로서 전승할 만한 보편적 가치를 지니는 자연의 기 념물, 생물의 종의 생식지 및 자생지, 자연지역이나 자연유적지 등'을 말 한다(http://whc.unesco.org). 자연유산의 정의에는 특히 '동물 및 생 물의 종의 생식지 및 자생지'로서의 지역을 포함하고 있다.

문화유산이란 사람들이 세상에 처음 나타났을 때 그때의 자연 상태에 머무르지 않고 살아가면서 서서히 문명의 이기를 발전시키며 그 발전된 모든 것이 지금까지 존재해 왔고 또 후대에 계승-상속될 만한 가치를 
지닌 예전시대의 문화적 소산 전부를 지칭하는 것으로 정의할 수 있다 (Wikipedia, 2011). 유네스코에 의하면 문화유산은 기념물, 건조물군, 유적지로 분류된다.2)

문화유산이 자연유산과 다른 점은 자연유산이 자연의 소산이라면 문화 유산은 인공의 소산이거나, 인공과 자연의 결합의 소산이라는 점이다. 특히 문화유산을 인공과 자연의 결합의 소산이라는 측면에서 보면, 문화 유산의 정의 속에 농업과 관련된 구조물, 유적지 등을 포함시킬 수 있는 여지가 있다. 때문에 일부에서는 세계농업유산제도를 별도로 운영할 것 이 아니라 세계문화유산제도의 틀 안에서 운영하면 되지 않느냐 하는 의 문을 제기한다.

복합유산 또는 문화적 경관이란 문화유산의 지정이 점(點)적인 지정에 치우쳤다는 점에 대한 반성으로 면(面)적인 보존을 목적으로 1994년에 도입된 개념으로, 인간이 자연에 가한 물리적이고 정신적인 관계가 나타 난 지역을 의미하여 종래의 문화유산과 자연유산의 중간에 유치하는 개 념이다(김란기, 2005; 오민근, 2005).

\section{3. 유럽의 농촌유산 개념}

농촌유산의 개념은 그동안 막연하게 사용되어 오던 것이 유럽농촌유산 가이드(European rural heritage observation guide)에서 구체화되

2) 기념물에는 건축물, 기념적인 의의를 갖는 조각 및 회화, 고고학적 성격을 띠고 있는 유 물 및 구조물, 금석문, 혈거 유적지 및 혼합유적지 중 역사, 예술 및 학문적으로 현저하 게 세계적 가치를 갖는 유산이 포함된다. 건조물군에는 독립된 또는 연속된 구조물들, 그의 건축성, 균질성, 입지성으로부터 역사적, 미술적으로 현저한 보편적 가치를 갖는 유산이 포함된다. 유적지에는 인공의 소산 또는 인공과 자연의 결합의 소산 및 고고학적 유적을 포함한 구역에서 역사상, 관상상, 민족학상 또는 인류학상 현저한 보편적 가치를 갖고 있는 유산들이 포함된다. 이상과 같은 문화유산의 분류에서 보면 문화유산에는 인 간의 문화생활과 관련된 가치 있는 것은 거의 모두를 포함하고 있음을 알 수 있다. 
어 등장되었다(CEMAT, 2003). 이 가이드에서는 농촌유산(rural heritage)이라는 개념이 지금까지는 농업활동과 연관된 구조물을 의미 하는 좁은 의미로 정의되어 왔다는 점을 지적하고 유산의 개념을 보다 넓게 정의하여 인간사회가 시간에 걸쳐 한 지역과 관계를 맺으면서 확립 한 특정관계를 나타내는 모든 유형적, 무형적 요소를 포함하는 것으로 정의하고 있다. 즉 농촌유산을 크게 유형적 유산과 무형적 유산으로 분 류하였다. 유형적 유산은 경관(landscapes), 자산(property), 산출물 (products)을 포함하며, 무형적 유산은 기술과 기능, 방언, 음악, 구전 문학 등을 포함한다.

농촌유산에는 경관이외에 분리된 개체로서의 자산, 각종 지역 생산물 등을 유산에 포함시키며 이외에도 관습, 방언, 문학 등 무형적인 요소 역 시 유산에 포함시키고 있다.

\section{4. 일본의 문화적 경관 개념}

일본의 문화적 경관은 유네스코의 복합유산제도에 영향을 받아서 기존 에 건축물 위주로 이루어지던 문화재 지정에서 탈피하여 넓은 의미에서 문화유산을 다루자는 취지에서 도입되었다. 일본의 문화적 경관이란 '농 산어촌지역의 자연, 역사, 문화를 배경으로 전통적 산업 및 생활에 밀접 하게 관련하며, 그 지역을 대표하는 독특한 토지이용 형태 및 고유의 풍 토를 나타내는 경관으로 가치가 높은 것'을 의미한다(김란기, 2005).

일본의 문화적 경관 개념에는 '전통적 산업 및 생활과 관련하여', 그리 고 '토지이용 형태 및 경관’이라는 두 가지 핵심적 개념요소가 들어 있다. 전자는 일본의 문화적 경관이 대상범위를 농어업뿐만 아니라 광업, 제조 업과 같은 전통적 산업, 그리고 산업 이외에 도로, 광장, 담장 등과 같은 전통적 생활에 관련된 것도 포함한다고 규정하고 있다. 그리고 후자는 
구체적 대상을 규정하고 있다. 이 부분은 $\mathrm{FAO}$ 의 농업유산에서 본 바 있 는 'land use systems and landscapes'의 개념요소와 동일하다. ${ }^{3)}$

일본은 국내의 농업유산은 문화적 경관제도에 의해 문부과학성이 주관 하고, $\mathrm{FAO}$ 의 GIAHS에 등재되는 농업유산은 농림성이 주관한다. 국내 의 농업관련유산을 문부성이 주관하는 것은 농업유산을 다른 문화재와 함께 통일되게 관리한다는 측면에 강점이 있다. 그러나 동일한 대상을 서로 다른 부서가 담당하고 있다는 점은 관리나 운영의 면에서 불합리한 측면이 있다.

\section{5. 한국 농어업유산의 개념제시}

\subsection{1. 제 개념의 관계분석}

먼저 유네스코의 문화유산과 $\mathrm{FAO}$ 의 농업유산의 개념을 비교하면 문 화유산의 개념으로는 $\mathrm{FAO}$ 의 농업유산의 개념을 커버하지 못하는 부분 이 존재한다. 문화유산제도에서 지정하는 문화유산은 고정된 농업 구조 물, 또는 농업유적지라는 분리된 개체만을 의미한다면, $\mathrm{FAO}$ 의 농업유산 은 고정적 구조물 또는 유적지가 현재의 농업활동과 관련성이 있고 생물 다양성4)이 보존되고 있는 복합체로서의 경관을 의미한다. 따라서 문화

3) 일본의 문화적 경관에 의한 분류는 다음과 같다. 논, 밭 등의 농경에 관한 경관지, 목 축지, 초지 등의 採草(채초), 방목에 관한 경관지, 用材(용재)림, 방재림 등의 산림의 이용에 관한 경관지, 양식장, 김 채취장 등 물고기 잡는 것에 관한 경관지, 저수지, 수로 항구 등 물의 이용에 관한 경관지, 광산, 채석장, 공장지대 등의 채굴, 제조에 관한 경관지, 도로, 광장, 등의 유통, 왕래에 관한 경관지, 담, 정원 등의 주거에 관한 경관지, 그리고 상기의 제시한 경관지가 복합적으로 이루어진 것을 포함한다.

4) $\mathrm{FAO}$ 에서 말하는 생물다양성은 자연 상태로 존재하는 생물다양성이 아니라 농업활동 과 관련된 토지이용체계에서 존재하는 생물다양성을 의미한다는 점에서 구별된다. 즉 자연유산은 자연 상태로서의 생물의 생식지나 자생지를 지칭한다면 $\mathrm{FAO}$ 에서 말하는 생물다양성은 인간의 농업활동과의 관계 속에서 인간에게 유익한 편익을 제공하는 생 물군의 유지를 의미한다는 점에서 구별된다. 
유산의 개념으로 $\mathrm{FAO}$ 의 농업유산 개념을 모두 포함하지 못하는 부분이 존재한다.

그러나 유네스코의 문화적 경관의 개념 카테고리 속에 $\mathrm{FAO}$ 의 농업유 산의 개념이 포함될 수 있는 개연성이 존재한다.5) 대상의 범위에서 보 면 문화적 경관이 $\mathrm{FAO}$ 의 농업유산을 포함한다. 여기에는 농림수산업관 련 경관은 물론 다른 산업도 포함하기 때문이다. 그러나 유네스코의 문 화적 경관의 개념은 $\mathrm{FAO}$ 에서 강조하는 농업의 활동적 측면(또는 농업 의 기능적 측면)을 고려하지 않고 있다. 즉 $\mathrm{FAO}$ 의 농업유산에서는 생물 다양성의 보존, 식량의 공급 및 지역사회의 유지 기능 등 소프트웨어적 측면을 강조한다는 점에서 유네스코의 문화적 경관과 차별된다. 이는 동 일한 대상의 유산을 서로 다른 두 개의 국제기구가 각각 운영하고 있는 이유이다. FAO의 농업유산제도는 유네스코에 의한 세계유산의 지정에 서 얻은 경험에다 농업활동으로서의 토지이용시스템과 이와 관련된 생물 다양성의 측면을 새롭게 강조하여 만들어진 것으로 볼 수 있다.

일본의 문화적 경관 개념은 유네스코의 문화적 경관을 참고하여 만들 어졌으므로 $\mathrm{FAO}$ 의 농업유산 개념과의 관계에 대한 설명은 위와 큰 차 이가 없다. 일본의 경우 문화적 경관 개념을 구체적으로 정의하고 그 대 상을 분류하고 있으므로 이를 바탕으로 $\mathrm{FAO}$ 의 농업유산 개념과 비교하 면 다음과 같다. 일본의 문화적 경관에서는 농촌에 존재하는 전통적인 것으로 가치 있는 것은 농업활동과 직접적 관련이 없어도 모두 문화적 경관에 포함시키고 있다. 예컨대 산업시설, 담, 정원 등의 주거에 관한 경관지는 농업활동과 직접적 관련이 없을지라도 문화적 경관에 포함시키 고 있다. 즉 일본의 문화적 경관은 대상범위를 농업뿐만 아니라 모든 전

5) 특히 유네스코의 문화적 경관 중 제 2 영역인 '유기적으로 진화하는 경관(organically evolved landscapes)'에는 농림수산업 등의 산업과 관련하여 계속되는 경관이 포함 되어 있다. 
통적 산업 활동과 농촌생활로 확대시켰다. 그러나 일본의 문화적 경관 개념 역시 해당 경관지역에서 이루어지고 있는 농업의 활동적 측면을 고 려하지 않고 있다는 점에서는 $\mathrm{FAO}$ 의 농업유산 개념을 모두 포괄하지 못한다.

다음으로 $\mathrm{EU}$ 의 농촌유산과 $\mathrm{FAO}$ 의 농업유산 개념을 비교하면 다음과 같다. $\mathrm{EU}$ 의 농촌유산의 분류에는 $\mathrm{FAO}$ 의 농업유산에서와 같이 경관을 중요한 요소로 포함하고 있다. 농촌유산에서 경관(landscapes)이란 단 순한 자연경치와 달리 인간이 환경에 작용한 결과로 만들어진 자연과 인 공물의 결합체를 말한다는 점에서 $\mathrm{FAO}$ 와 동일하다. 그러나 다른 점은 농촌유산에서의 경관은 단지 농촌에 존재하는 가치 있는 인공물, 또는 유적지 등과 이들을 포함한 공간으로서, 현재의 농업과 직접적으로 관련 이 있는 것은 물론이고 관련이 없는 것도 포함한다. 이에 반해 $\mathrm{FAO}$ 의 농업유산은 현재 농업활동이 이루어지고 있는 경관만을 대상으로 한다는 점에서 차이가 있다. 면적인 대상의 범위에서 보면 $\mathrm{EU}$ 의 농촌유산이 $\mathrm{FAO}$ 의 농업유산을 포함한다. 그러나 $\mathrm{EU}$ 의 농촌유산개념 역시 $\mathrm{FAO}$ 의 농업유산 개념을 커버하지 못하는 부분이 존재한다. 즉 $\mathrm{FAO}$ 의 농업유 산은 농업활동을 증명하는 토지이용시스템 및 농업활동과 연관된 생물다 양성의 유지를 중요한 개념요소로 포함하지만 $\mathrm{EU}$ 의 농촌유산에는 이에 대한 고려가 없다.

종합하면 유네스코의 문화유산과 자연유산의 중간에 위치하는 개념이 농촌유산과 문화적 경관이다. 특히 문화적 경관은 $\mathrm{FAO}$ 의 농업유산의 개념에 가장 가깝다.6) 면(面)적으로 대상범위를 비교하면 $\mathrm{FAO}$ 의 농업 유산은 문화적 경관에 포함된다(〈그림 1〉). 그러나 $\mathrm{FAO}$ 의 농업유산은 경관이라는 면적요소 위에서 이루어지는 전통적 농업활동을 중시하고 이

6) 농촌유산의 개념은 〈그림 1〉에 나타내지 않았지만 문화유산과 자연중간의 중간에 위 치하는 개념으로 문화적 경관보다는 넓은 개념으로 볼 수 있다. 
의 결과로 나타난 토지이용시스템과 생물다양성을 강조한다는 점에서 차 이가 있다.

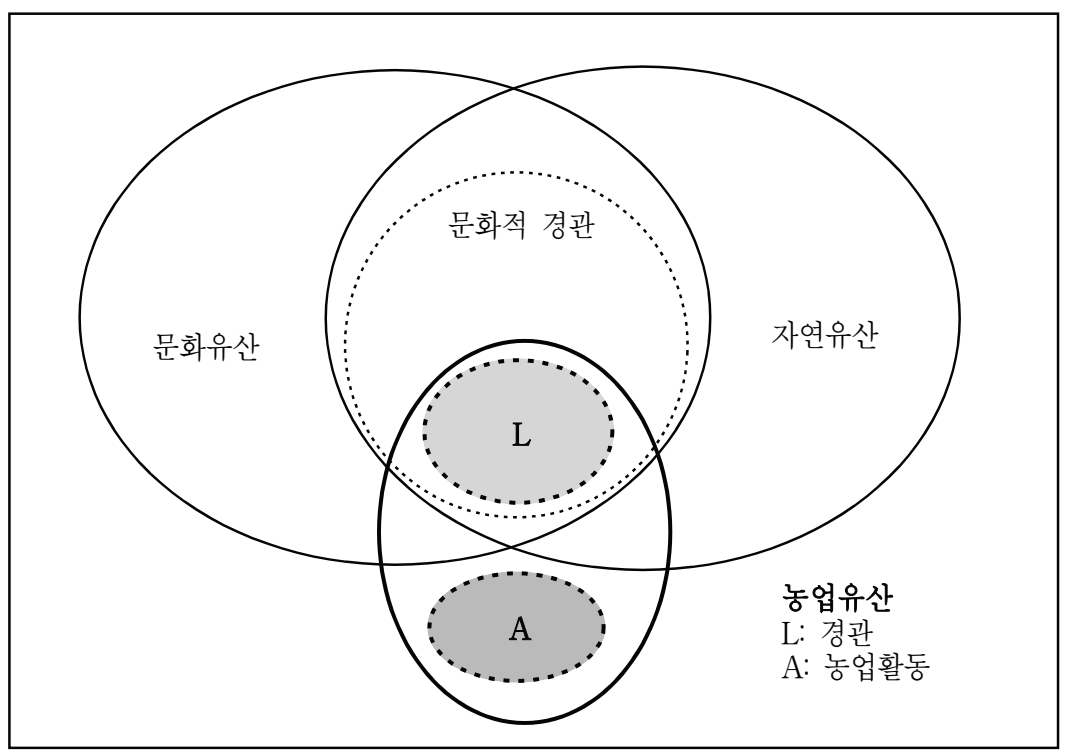

자료: 윤원근, \& 최식인. (2011). 한국 농어업 - 농어촌 유산발굴과 보전. 농업전망2012. 농 촌경제연구원, 325 .

〈그림 1〉 제 개념 간의 관계

\subsection{2. 한국농어업유산의 개념제시}

이 연구는 위에서 논의한 제 개념들 간의 관계분석을 통해서 한국의 농어업유산의 개념을 정립한다. 이때 $\mathrm{FAO}$ 의 농업유산개념이 가장 좋은 참고가 될 수 있다.

우리의 농어업유산개념을 정립함에 있어서 다음의 개념요소를 포함하 도록 한다.

첫째는 농어업유산은 농어업과 관련이 있어야 한다. 이는 농어업유산 
을 문화유산이나 농어촌유산과 구별 짓는 기준이 된다. 즉, 농어업유산 은 농어촌에 있는 문화적인 요소들을 모두 대상으로 하는 것이 아니라 농어업과 관련된 것만을 대상으로 한다.

둘째는 농어업유산에서는 현재 농어업활동이 이루어지고 있어야 한다. 농어업유산에서는 현재 농어업활동이 계속되고 있으며, 이러한 농어업활 동은 지역사회에 산출물(식량 등)을 공급하며, 지역사회를 유지하는 기 능을 하며, 생물다양성을 유지하는 기능을 하며, 지역사회의 문화형성과 깊은 관련성을 맺고 있어야 한다.

셋째는 농어업유산은 장소를 대상으로 지정한다. 농어업유산은 인간이 자연에 대하여 작용한 결과로서 만들어진 복합체(continuum)로서의 경 관을 대상으로 지정한다. 이 경우에 무형유산은 단독으로 농어업유산에 지정될 수 없지만, 농업유산에 무형적 요소가 포함될 수는 있다.

이상과 같은 개념의 정립 방향을 고려하여 우리나라의 농어업유산의 개념을 다음과 같이 정의한다. 즉, 농어업유산이란 '농림어업인이 지역 사회의 문화적, 농업적, 또는 생물학적 환경과 깊은 관계를 맺으면서 적응과정을 통해서 진화해온 보전 - 유지 및 전승할만한 가치가 있는 전 통적 농어업활동과 이의 결과로서 나타난 농어촌의 경관으로 정의할 수 있다. 7)

7) 우리나라 농어업유산의 개념에 부합되는 사례로 구들장 논, 전통적인 다랑이 논과 밭 등을 들 수 있으며 2012년 6월 현재 농식품부는 시·군으로부터 농어업유산으로 지 정 가능한 품목을 신청받고 있으며 현재까지 알려지지 않은 다수의 농어업유산이 발 굴되고 있다. 


\section{3. 국내외 농어업유산관련 제도의 분석}

농업유산과 관련된 대표적인 국내제도로는 문화재보호법에 의한 국가 지정문화재로의 지정이 있고 해외제도로는 세계문화유산제도, 람사협약 제도,8) 세계농업유산제도(GIAHS) 가 있다. 이 연구에서는 가장 대표적 인 문화재보호법의 제도와 세계농업유산제도의 검토를 통해서 제도도입 을 위한 문제점 및 시사점을 도출하고자 한다.

\section{1. 문화재보호법에 의한 유산관리}

\subsection{1. 문화재보호법에 의한 유산지정 및 관리실태}

한국의 문화재 전반에 대한 체계적인 분류와 보전정책은 문화재청에서 담당하고 있고, 문화재보호법(1962)의 제정을 통하여 운용되고 있다 (www.cha.go.kr).9) 국가지정문화재와 시- 도지정문화재, 문화재자료,

8) 람사협약의 목적은 세계적으로 중요한 습지의 파괴를 저지하기 위하여 1971년 2월 2 일 이란의 람사(Ramsar)에서 람사협약이 체결되었으며, 람사협약의 정식 명칭은 '물 새 서식지로서 특히 국제적으로 중요한 습지에 관한 협약(Convention on Wetlands of International Importance especially as Waterfowl Habitat)'이다. 람사협 약에서 말하는 습지란 자연적인 것과 인공적인 것 모두를 포함하며, 영구적인 것이나 일시적인 것이나 상관하지 않고 있음. 또 물이 정체하고 있거나, 흐르고 있거나, 담수, 기수(강어귀 바닷물), 함수(바닷물)에 관계없이 소택지, 늪지대, 이탄지역 또는 수역을 말한다. 제 10 차 람사르회의(창원 2008)에서 논도 하나의 습지로서 결의된 바 있다.

9) 문화재관리법 이외에, 농어업-농어촌유산 중에서 무형자산의 기록과 전승을 위한 사 업으로서 특허청의 전통지식자원 구축사업이 있다. 전통지식이란 전통에 기반을 둔 지적활동의 산물로서 파생되는 산업, 예술 또는 문학적인 결과물을 총괄하고 생업자 원(농림축산어업의 기구, 기술, 시술), 생활기술(의, 식, 주, 전통의료), 창조적 기술 (문화적, 제도적 기술)로 분류된다. 환경부와 국토해양부는 농촌공간의 생물다양성과 생태계를 보호하기 위하여 1991년 자연환경보전법을 제정하여 생태경관보전지역과 생태경관마을을 지정하여 운용하고 있다. 주로 자연 상태가 원시성을 유지하고 있거 나, 생물다양성이 풍부한 곳, 자연경관이 수려한 곳 등을 대상으로 하고 있기 때문에, 농어업 - 농어촌 유산 중에서 자연유산과 관련성이 많다. 
등록문화재, 비지정문화재 등으로 구분하고, 문화재의 지정을 위하여 문 화재위원회를 두고 있다. 국가지정문화재는 문화재청장이 문화재보호법 에 의거 문화재위원회의 심의를 거쳐 지정한 중요 문화재로서 국보, 보 물, 사적, 명승, 천연기념물, 중요무형문화재, 중요민속문화재 등 7 개 유 형으로 구분되어 지정·관리되고 있다.

국가지정문화재는 2010년 현재 3,326개가 지정되어 관리되고 있다. 보물이 1,667 개(50.1\%)로서 가장 많은 비중을 차지하고, 사적이 491개 (14.8\%), 천연기념물 407개(12.2\%)의 순으로 나타난다.

국가지정문화재의 목록을 기초로 농어업·농어촌유산과 관련성이 있 는 품목들의 재분류를 통하여 현행의 문화재보호법은 과연 농어업·농어 촌 유산을 충분하고 적정하게 지정하고 관리하고 있는지에 대한 판단이 요구된다. 농림어업활동과 관련성이 있거나, 농어촌주민의 일상적인 삶 과 관련이 있는 시설물형태의 문화재를 추출하여 재분류를 통하여 지정 및 관리형태의 분석한 결과는 다음과 같다.

농어업 - 농어촌 유산과 관련된 시설물 형태의 문화재는 총 3,326 개의 문화재 중에서 399개(12\%) 정도로 나타난다. 농어업 - 농어촌 유산과 관련성이 높은 문화재의 품목은 〈표 1〉에서 보는 바와 같이, 399개의 관 련문화재 중에서 농어업유산의 경우 17 개(4.3\%), 농어촌유산은 382 개 (95.7)의 문화재가 포함되어 있다. 농어업유산은 17 개에 불과하고, 농 업과 관련된 시설로서 저수지(백골제, 의림지), 다랑이 논, 방아와 관련 된 시설, 곳간, 외양간 등이 있고, 어업과 관련하여서는 남해 죽방렴 1 개 가 포함되어 있다. 농어촌유산을 세분해 보면, 주택과 관련된 시설이 322 개(80.7\%)로서 절대 다수를 차지하고 있고, 마을전체가 지정된 곳 은 안동하회, 경주양동마을 등의 민속마을이 7 개 지정되어 있다.

문화재보호법에 의해서 일단 문화재로 지정되면 문화재 보호를 위하여 보호물이나 보호구역을 지정할 수 있고(제27조), 문화재의 형상변경이나 
보존에 영향을 미치거나 동식물의 채취 또는 반출의 우려가 있는 경우 는 허가를 받아야 하는 등의 규제를 하는 반면에, 필요한 경우에 관람료 의 징수가 가능하고, 필요경비는 국가 또는 지자체로부터 지원받을 수 있다.

〈표 1〉국가지정 문화재로 지정된 농어업·농어촌유산의 분류

(단위: 개)

\begin{tabular}{|c|c|c|c|}
\hline \multicolumn{2}{|c|}{ 구분 } & 내용 & 지정현황 \\
\hline \multirow{5}{*}{$\begin{array}{l}\text { 농어업 } \\
\text { 유산 }\end{array}$} & 국보 & - & - \\
\hline & 보물 & - & - \\
\hline & 사적 & 김제 백골제 & $1(0.3)$ \\
\hline & 명승 & 남해가천다랑이논, 제천의림지와 제림, 남해 죽방렴 & $3(0.7)$ \\
\hline & $\begin{array}{l}\text { 중요민속 } \\
\text { 문화재 }\end{array}$ & $\begin{array}{l}\text { 삼척물레방아(1), 삼척통방아(2), 제주말방아(3), 달성 } \\
\text { 곳간(2), 영천곳간(1), 청송곳간(1), 안동외양간(1), 안 } \\
\text { 동방아간(1), 안동곳간채(1) }\end{array}$ & 13(3.3) \\
\hline \multirow{7}{*}{$\begin{array}{l}\text { 농어촌 } \\
\text { 유산 }\end{array}$} & 국보 & - & - \\
\hline & 보물 & $\begin{array}{l}\text { 양동 무첨당-향단, 경주 독락당, 강릉 오죽헌, 하회 } \\
\text { 충효당 }\end{array}$ & $5(1.2)$ \\
\hline & 사적 & 해남윤씨 녹우당 일원 & $1(0.3)$ \\
\hline & 명승 & 정자, 숲, 원림, 정원 등 & 15(3.7) \\
\hline & \multirow{3}{*}{$\begin{array}{l}\text { 중요민속 } \\
\text { 문화재 }\end{array}$} & $\begin{array}{l}\text { 주택(고택, 가옥, 너와집(3), 굴피집(1), 투막집(2), 호지 } \\
\text { 집(1), 초가(1) 등) }\end{array}$ & $316(79.2)$ \\
\hline & & 기타(장승, 당집, 정자, 제당·사당, 연못 등) & $38(9.5)$ \\
\hline & & $\begin{array}{l}\text { 민속마을(안동하회, 경주양동, 아산외암, 성주한개, 고 } \\
\text { 성왕곡, 제주성읍, 순천낙안읍성) }\end{array}$ & $7(1.7)$ \\
\hline \multicolumn{3}{|r|}{ 계 } & $399(100.0)$ \\
\hline & & 국가지정문화재 계(2010) & 3,326 \\
\hline
\end{tabular}

주: 1) 국가지정문화재에 포함된 농어업·농어촌 유산과 관련된 품목을 재분류

2) 농어업유산은 농림어업활동과 관련성이 있는 시설물

3) 농어촌유산은 농촌주민의 일상적인 생활양식과 관련된 시설물

4) 중요무형문화재, 천연기념물은 제외하였음

5) 유형유산을 대상으로 하되, 자연유산은 분류에서 포함시키지 않았음

자료: www.cha.go.kr/main/ 


\subsection{2. 문제점}

문화재보호법에 의한 지정 및 관리 실태에서 나타난 문제점은 다음과 같다. 첫째, 문화재보호법에 의해서 지정 - 관리되고 있는 농어업·농어촌 과 관련된 유산은 농어촌에 분포하고 있는 유산의 일부를 대상으로 하고 있다. 농어업유산은 17 개에 불과할 정도로 그 수가 매우 적어서, 농어 업의 유형과 특성에 따라 전반적이고 체계적인 유산발굴과 관리가 시급하 다는 것을 시사하고 있다. 농어촌과 관련된 유산은 382 개에 이르고 있 으나, 대부분이 주택으로 이루어져 있다는 것을 알 수 있으며, 주택이외 의 다양한 농어촌유산의 발굴과 지정이 필요하다는 것을 시사하고 있다.

둘째, 문화재보호법의 문화재로 지정되지 못한 많은 농어업·농어촌 유산은 지역의 상황에 따라서 과 이용 또는 방치되거나, 자연재해 및 개 발행위 등으로 파괴되고 있는 상황으로 전개되고 있다.

셋째, 문화재보호법의 국가지정문화재의 보호방식은 농어업- 농어촌 유산이라는 특수성을 반영하지 못하고 있다. 남해 가천 다랑이 논의 경 우, 명승으로 지정되어 있으나, 명승은 주로 경관을 중시하는 측면에서 지정 - 관리되는 제도로서, 다랑이 논이라는 농업적 특성, 예를 들면, 농 법, 다랑이논의 구조, 다랑이논의 축조 방법, 생물다양성 등의 특수성이 지정 및 보전방법에서 감안되지 못하고 있다. 경관과 시설물이 만들어지 게 된 원인이 되는 무형적인 전통지식이나 전통기술이 종합적으로 접근되 지 못하고, 시설물 자체만을 대상으로 하는 데서 오는 한계를 노정한다.

넷째, 문화재보호법에 의한 국가지정문화재의 지정은 주민이 기피하 고, 지역사회와 관련성을 맺지 못하는 경우가 많다. 유산이 지역주민과 도시민의 관심에서 멀어진 채 섬처럼 남아있는 모습을 보이고 있으며, 규제적 성격의 문화재 보존방식은 주민들이 외면하는 요인이 되고, 지역 사회의 자랑거리가 되지 못하고, 나아가서는 지역사회의 성장을 위한 보 존 및 활용계획과 연계되지 못하고 있다. 


\section{2. 세계농업유산제도의 실태와 시사점}

\subsection{1. 세계농업유산제도의 실태}

세계농업유산(Globally Important Agricultural Heritage Systems) 은 농어업유산의 개념에서 언급한 바와 같이10) 통상적인 유적지나 경관 보호의 개념과 다소 구별되고, 인간 공동체가 환경과 깊은 관계를 맺으 면서 진화하는 생물다양성이 풍부한 생명력 있는 체제를 의미한다 (www.fao.org/nr/giahs).11)

$\mathrm{FAO}$ 는 세계적으로 중요한 전통적 농업제도와 생물다양성, 문화적 다 양성과 지식체계들이 정책 및 시장의 실패, 빈곤 및 인구 압력, 부적절한 개발전략 등으로 인하여 심각한 위협을 받고 있는 상황을 인식하고, 세 계적으로 중요한 농업유산에 대한 인식제고와 국제적으로 인가된 제도를 만들자는 취지에서 발의하였다. 세계적으로 중요한 농업유산(GIAHS)의 보전을 위한 혁신적 체계와 동태적 보전을 강화하는 장기적 프로그램을 촉진하자는 데에 그 발의의 목적이 있다.

$\mathrm{FAO}$ 는 2011년 현재 10개의 대상지역(Pilot systems)12)과, 다수의 후보지역(Candidate systems)을 지정하고 있다. 필리핀의 이푸가오 다랑이 논, 중국 운남성의 하나 다랑이 논, 잉카유적지 등은 전 세계적인

10) GIAHS are defined as remarkable land use systems and landscapes which are rich in globally biological diversity evolving from the $\mathrm{co}^{-}$adaptation of a community with its environment and its needs and aspirations for sustainable development (www.fao.org/nr/giahs).

11) A GIAHS is a living evolving system of human communities in an intricate relationship with their territory, cultural or agricultural landscape or biophysical and wider social environment(www.fao.org/nr/giahs).

12 ) 가장 최근에 지정된 세계농업유산은 2011. 6월에 지정된 일본의 사례임. 하나는 니 이가타현(新瀉縣) 사도시(佐渡市)의 사례로서 국가천연기념물인 따오기와 함께 공생 하기 위하여 저농약 벼농사에 나서고, 이시가와현(石川縣) 노토(能登) 반도는 계단식 논과 해변농작 등 사토야마 사토우미(里山里海)로 등록되었다. 
경관이면서, 특수한 농법이라는 면에서, 우리나라의 다랑이 논과 비교할 수 없는 정도의 수준과 규모를 보이고 있다.

다른 한편으로는 일본의 사도시의 따오기와 같이 공생하기 위하여 저 농약을 사용하여 생물다양성을 높이고 주변의 다랑이 논을 대상으로 지 정된 사례와 중국 완족의 경우 고유품종으로서, 병충해와 척박한 땅에 강한 품종을 유지하면서 논의 둘레 숲의 물 공급 및 생물다양성 보전기 능을 가진 제도로 지정된 사례는 우리에게도 세계농업유산의 지정에 대 한 도전 가능성을 보여주고 있다고 생각된다.

〈표 2〉 $\mathrm{FAO}$ 의 세계농업유산 지정지역(pilot system)

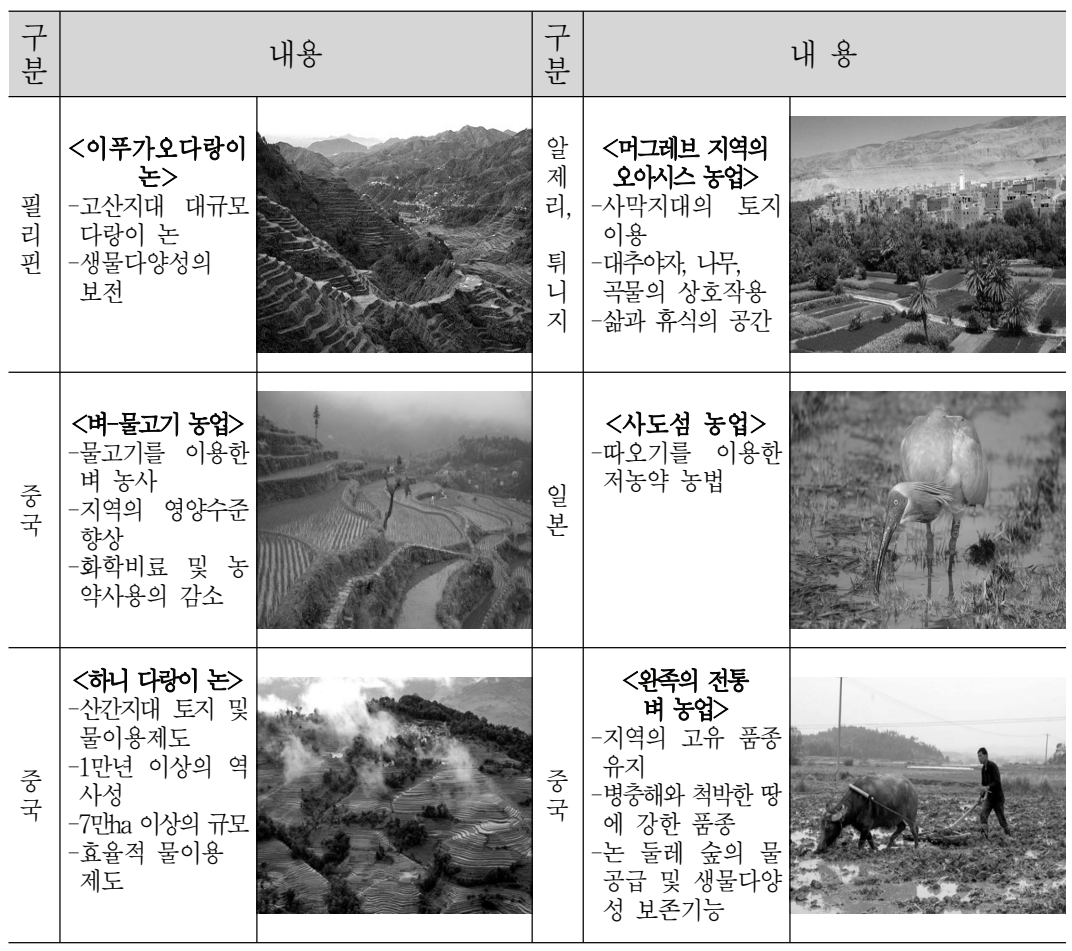




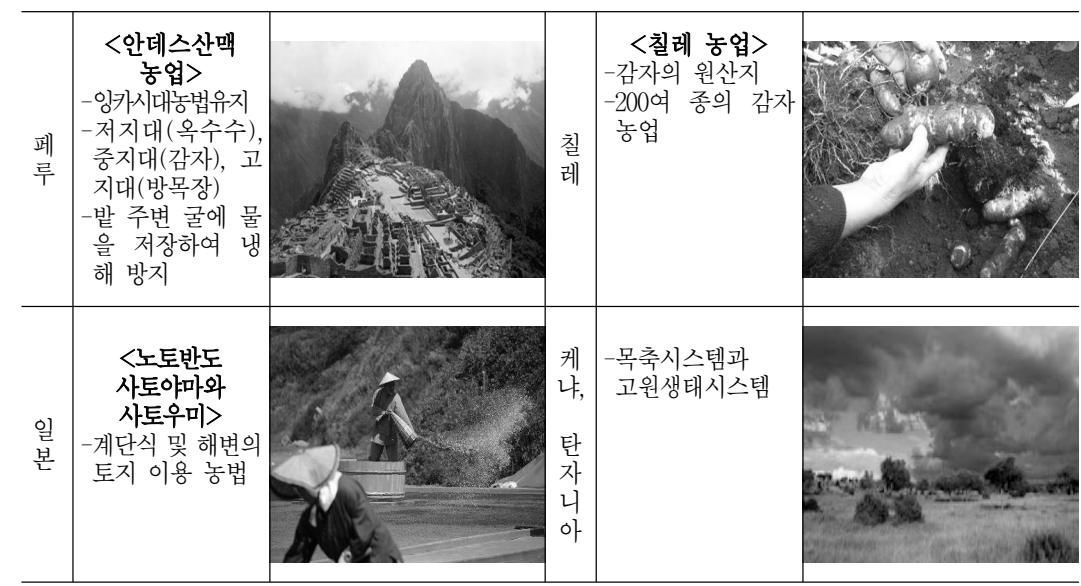

자료: www.fao.org/nr/giahs

GIAHS에 등록되기 위한 기준은 크게 세 가지로 구분되고 있으며, 첫 째는 해당 제도의 고유한 특성에 관한 기준이고, 둘째는 정황적 기준, 셋 째는 프로젝트 수행 기준이다(〈표 3〉).

〈표 3〉 GIHAS 선정기준

\begin{tabular}{|c|c|c|}
\hline 구분 & 기준 & 내용 \\
\hline \multirow{3}{*}{$\begin{array}{l}\text { I. 제도의 } \\
\text { 고유특성 } \\
\text { (systems } \\
\text { criteria) }\end{array}$} & $\begin{array}{l}\text { 1. 현저한 특징 } \\
\text { (outstanding characteristics) }\end{array}$ & $\begin{array}{l}\text {-생물다양성과 생태시스탬 } \\
\text {-경관, 토지, 수자원의 관리 } \\
\text {-식량안전과 생계유지 } \\
\text {-사회조직과 문화 } \\
\text {-지식체계와 및 농가 단위의 기술 } \\
\text {-기타 제도에 의해서 형성된 재화 } \\
\text { 와 용역 }\end{array}$ \\
\hline & $\begin{array}{l}\text { 2. 지속성의 역사 } \\
\text { (proved history of sustainability) }\end{array}$ & $\begin{array}{l}\text {-경제적 활력 및 지속가능성 } \\
\text {-적응적 능력 } \\
\text {-인간 생태적 지속가능성 }\end{array}$ \\
\hline & \begin{tabular}{|l} 
3. 세계적 중요성 \\
(global significance)
\end{tabular} & $\begin{array}{l}\text {-공공성 } \\
\text {-부가가치 }\end{array}$ \\
\hline
\end{tabular}




\begin{tabular}{|c|c|c|}
\hline \multirow{3}{*}{$\begin{array}{l}\text { ․ 정황성 } \\
\text { (contextual } \\
\text { criteria) }\end{array}$} & 1. 대표성(representation) & $\begin{array}{l}\text {-지리적, 생태적, 제도적 대표 } \\
\text { 성 및 영향력 } \\
\text {-전시효과 } \\
\text {-현저한 대표성 }\end{array}$ \\
\hline & 2. 외부의 위협(external threat) & -외부적 위협의 존재 \\
\hline & $\begin{array}{l}\text { 3. 정책 및 개발 적용성 } \\
\text { (policy and development relevance) }\end{array}$ & -정책의 적용가능성 \\
\hline \multirow{3}{*}{$\begin{array}{l}\text { III. 프로젝트 } \\
\text { 수행성 } \\
\text { (project } \\
\text { implementation } \\
\text { criteria) }\end{array}$} & $\begin{array}{l}\text { 1. 프로젝트 통합성 } \\
\text { (project integration) }\end{array}$ & -파트너십 \\
\hline & $\begin{array}{l}\text { 2. 공동 펀드의 능력 } \\
\text { (co-finance potential) }\end{array}$ & -공동 펀드 가능성 \\
\hline & $\begin{array}{l}\text { 3. 프로젝트 접근성 } \\
\text { (project approach) }\end{array}$ & $\begin{array}{l}\text {-국제협약 } \\
\text {-프로그램적 접근 } \\
\text {-생태계적 접근 } \\
\text {-지역사회의 권한 } \\
\text {-분권화 }\end{array}$ \\
\hline
\end{tabular}

자료: www.fao.org/nr/giahs

특히, 제도의 고유특성에서 보듯이, GIAHS에서는 생물다양성과 생태 계 기능, 경관과 토지 및 수자원 관리, 식량과 생활의 안전, 사회조직과 문화, 지식체계와 농업기술, 그리고 이 제도에 의한 산출물 등을 중시하 고 있다. 정리하면 GIAHS에서는 경관자체만을 대상으로 하는 것이 아 니라 그곳에서 일어나고 있는 농림어업활동을 매우 중요한 기준으로 삼 고 있다. 즉 소프트웨어와 하드웨어를 분리하여 지정하는 것이 아니라 소프트와 하드시스템을 동시에 지정하고 있다.

\subsection{2. 시사점}

농어업유산과 관련된 제도로는 $\mathrm{UNESCO}$ 의 세계문화유산, 람사협약 등이 있지만, 가장 직접적인 관련성이 있는 제도는 $\mathrm{FAO}$ 가 별도로 운용 하는 세계농업유산제도(GIAHS) 임을 알 수 있다. 
$\mathrm{FAO}$ 에서 별도로 세계농업유산제도를 운용하는 이유는, 세계문화유산 은 무형적인 것과 유형적인 것을 분리하여 접근하고 있는데 반하여, 세 계농업유산은 농어업부문에 한정하여 물리적인 것뿐만이 아니라, 물리적 인 것을 형성하는 농어업활동에 대한 것까지도 동시에 포함하여 지정하 는 것에 있다고 판단된다.

우리나라의 경우 세계문화유산의 대상은 문화재보호법에 관련규정을 두고 문화재청에서 관련 정책을 수행하고 있고, 람사협약의 대응은 환경 부가 습지법을 제정하고 습지를 관리하고 있지만, 농어업유산에 대해서 는 그동안 방치되어 왔다. 우리나라도 $\mathrm{FAO}$ 의 세계농업유산제도와 관련 성을 맺으면서 국내에 분포하고 있는 농어업유산을 보전하고 관리할 수 있는 제도적 장치를 마련할 필요성이 있다는 것을 시사한다.

\section{4. 농어업유산제도의 방향설정}

\section{1. 제도 도입의 기본방향}

앞에서 살펴본 바와 같이 문화재보호법에 의해서 농어업유산의 일부가 지정 및 관리되고 있으나 많은 한계가 노정되고 있다. 따라서 농업의 특 수성을 반영하고 국제기구인 $\mathrm{FAO}$ 와의 연계성 등을 강화하기 위하여 농 어업유산제도의 도입이 필요한 것으로 판단되고 기존 부처의 제도와는 차별화된 유산제도가 고안되어야 한다.

첫째, 문화재보호법에서 다루고 있는 농어업유산과 관련된 문화재는 극히 제한적이고, 농어촌에 실제로 존재하고 있는 다수의 중요한 유산을 포함하고 있지 않다. 농어업유산제도의 도입을 통해서 그동안의 개발 중 심적 정책에 대한 반성을 통하여 현 시점에서 보존해야 할 것이 무엇인 
지, 그리고 남아있는 유산은 어떤 것이 있는지 실태를 파악하고 데이터 베이스를 구축하여야 한다.

둘째, 문화재보호법의 유산제도는 무형과 유형을 통합적으로 다루지 않기 때문에 농림어업유산의 특성을 반영할 수 없다. 농어업유산은 농림 어업활동과 그 결과로 나타난 통합적인 산물임을 직시해야 한다. 농어업 유산제도는 소프트웨어로서의 농림어업활동과 하드웨어로서의 경관을 통 합적으로 지정한다.

셋째, 문화재보호법의 유산제도는 원형보전을 제일 목적으로 하는 보 전 중심의 제도이다. 그래서 국가가 지정하고 있는 문화재는 주민들의 일상생활 및 생산 활동과 관련성을 맺지 못하는 경우가 발생하고 있다. 농어업유산은 보전도 하면서 지역주민의 소득 및 지역경제의 활성화에 도움을 줄 수 있는 방향에서 새롭게 검토될 필요성이 있다.13)

넷째, $\mathrm{FAO}$ 가 유네스코와는 별도로 농업유산제도를 운용하고 있는 흐 름과 추세를 인식하고, 국제기구의 제 활동에 대한 참여와 협력을 통하 여 농어촌개발사업의 국제화에 기여할 수 있어야 한다. 우리나라에서는

13) 농어업유산과 지역발전의 연관성은 일찍이 여러 학자들에 의해서 지적된 바 있다. 일 찍이 아담 스미스(A, Smith)는 분업에 의한 생산 활동에는 인간의 지식이나 숙련 등 과거의 문화적 요소를 계승하고 발전시킨다고 하는 측면이 들어 있음을 지적한 바 있다. 그의 견해에 따르면 현재의 생산 활동은 과거의 문화적 유산과 불가분의 관계 에 있다. 전통적 농어업 생산기술의 보존이 오늘날의 농촌개발과 밀접한 관련이 있다 는 점을 지적한 것이다. 마셜(A. Marshall) 역시 농업유산과 같은 유형의 유산은 '그 하나하나가 독특한 것으로 실제의 가치보다 높게 평가되고 있으며, 척도도 없고 경쟁상대도 없다.'고 지적하여 유산의 가치를 시장에서 평가될 수 없는 예외적인 것으 로 인정하고 있다(지상순 외, 1999, p. 26). 그의 견해에 따르면 농어업유산 자체, 또는 이로부터의 산출물에 대한 수요는 도시소비자들의 생활의 질에 대한 욕구가 높 아짐에 따라 당연히 증가한다. 그러나 공급측면의 생산성향상은 기대하기 어려우므로 농어업유산에 대한 가치는 예외적으로 높게 평가되는 측면이 있다는 것이다. 역사적 인 유산의 보존(preservation), 회복(rehabilitation), 복원(restoration)은 그러 한 유산을 보유하고 있는 지역의 경제적인 효과나, 역사지구의 의 재산 가치에 대하 여 매우 긍정적인 영향을 미치는 것으로 보고하고 있다(Sacit Hadi Akdede \& Emre Can, 2010; 135). 
현재까지 유네스코에 의한 세계문화유산에 대해서는 사회적 관심이 많았 으며 다수의 지정된 사례가 있으나 세계농업유산에 대해서는 사회적으로 잘 알려져 있지 않았으며 지정사례도 없다.

다섯째, 농어업유산에 대한 새로운 가치부여의 과정을 통해서 FTA이 후의 어려운 상황을 타개하는 데 도움이 될 수 있는 농촌발전의 신성장 동력을 찾아내고, 활용을 통하여 우리 농촌을 활성화시키는 방향에서 검 토되어야 한다. ${ }^{14)}$ 유산의 발굴과 보전은 경제성장의 과정에서 훼손되고 변형된 국토공간을 새로운 방향으로 재편하는 과정에서 정체성 있는 공 간창조의 유전인자가 될 것이다. 또한 농어업활동 및 경관의 체계적인 보존, 전승 및 활용을 통하여 우리의 농어촌공간을 보다 차별화시켜서 정체성 있고 활력있는 공간으로 재창출하는 데 기여할 수 있다.

\section{2. 제도정립과 관련된 주요내용}

\subsection{1. 근거법}

현재의 농식품부의 법률 중에서 농업유산과 관련된 규정을 두고 있는 법률로는 ‘농업농촌 및 식품산업기본법’이 있다. 동법 제45조에서는 국가 와 지방자치단체는 농촌의 자연환경을 보전하고 농촌경관의 형성, 보전, 관리 및 농업생태계보전 등에 필요한 정책을 수립, 시행해야 한다고 규 정하고 있으며, 제 46 조에서는 국가와 지방자치단체는 전통 농경문화, 농 경유물, 전통농법 등을 계승시키기 위하여 필요한 정책을 수립, 시행할

14 ) 이와 관련한 우리나라의 연구로는 유재한(2006), 최석호(2006), 이승구 \& 샤말레누 카(2008), 한숙영 \& 김사헌(2007) 등을 들 수 있다. 국외의 경우 Huynh Hoa Thuy Tien(2011)은 역사문화지구의 경제적 영향, 구직, 재산가치, 진정성, 문화적 신뢰, 믿음과 생활양식, 환경 등에 미치는 영향을 보고하였다. Confer \& Kerstetter (2000) 역시 문화유산관광은 항수와 문화역사 가치를 재인식하게 됨으로써 고부가가치 방문객을 유치하는 것으로 보고하였다. 
것을 규정하고 있다. 농촌경관, 농업생태보전, 농경유물, 전통농법이라는 농어업 - 농어촌 유산과 관련이 있는 용어가 사용되고 있으며, 보전을 위 하여 노력해야 한다는 포괄적인 규정을 두고 있으나, 구체적인 정책수립 및 시행을 위한 법률규정은 없는 것으로 판단된다.

'농업·농촌 및 식품산업기본법'의 하위 법률로서 농어업유산제도의 도 입과 운용에 대한 법률을 제정하는 것이 바람직하다고 생각된다. 농어업 유산제도는 활용이나 지원뿐만이 아니라 보존이나 복원 등의 규제의 내 용이 불가피하게 포함되어야 하고, 공익을 위한 개인의 자유권의 침해와 관련성이 있을 수 있기 때문에 법적인 근거규정은 반드시 필요하다고 생 각된다. 농어업유산의 농촌개발프로그램과의 관련성에 대한 부분은 농어 촌정비법의 토지이용과 관련된 규정을 개정하는 방향에서 검토될 수도 있을 것이다.

\subsection{2. 관련 국내외 기구와의 연계 및 체계화}

농어업유산제도는 국내의 관련부처의 역할분담 및 국제기구의 흐름에 부합되는 방향으로 체계화될 필요가 있다. 국내적으로는 문화재청의 문 화재보호법과는 별도의 법률체계로서 독립성을 유지하면서도, 국제적으 로는 $\mathrm{FAO}$ 가 운용하는 농업유산제도와 연계하는 방향으로 체계화될 필 요가 있다. 세계문화유산은 문화재청의 문화재보호법과 연계되고 있으 며, 람사협약을 통한 습지관리 등은 환경부의 자연환경보전법, 습지법과 관련성을 맺고 있는 반면에, 세계농업유산은 농업의 담당부처인 농식품 부와 관련성이 없는 상태에 있어 왔다(〈그림 2〉).

일반적인 문화재보호와 관련된 문화재보호법은 농어업이라는 특수한 유산의 발굴과 보호를 위한 제도로서 충분히 기능하지 못하고 있고, 농 어업유산을 종합적이면서, 전문적으로 다룰 수 없다는 면에서 한계가 노 정되고 있다. 


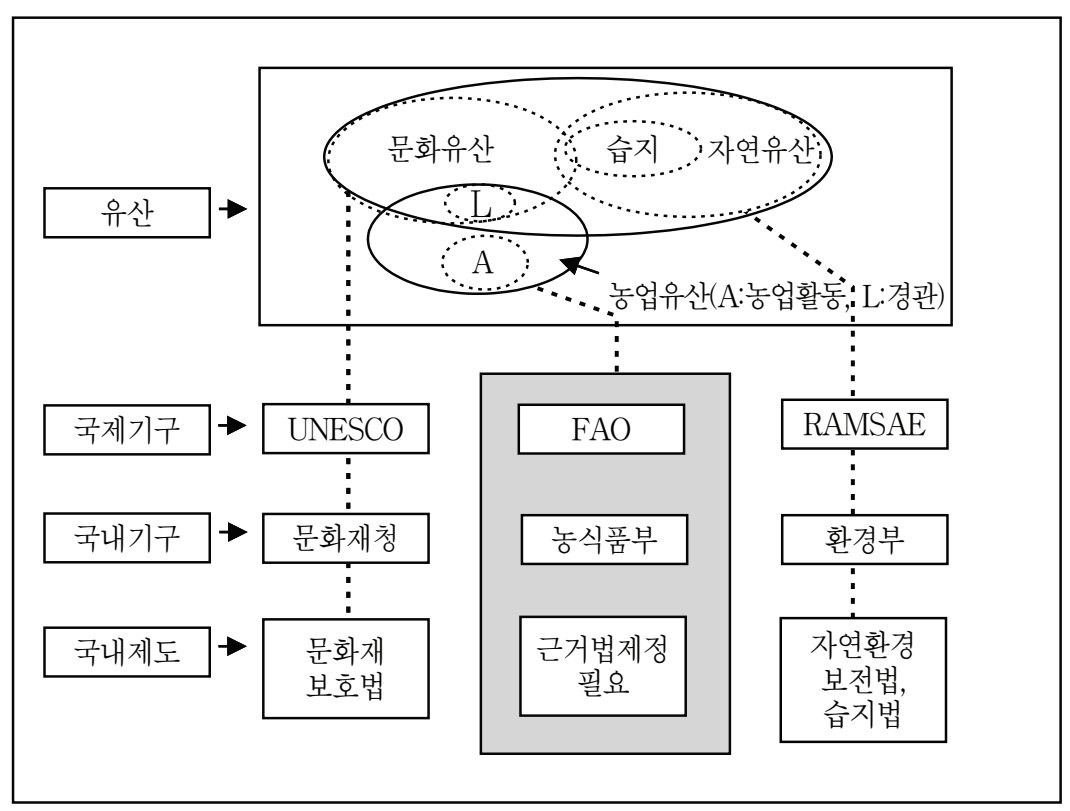

자료: 윤원근 \& 최식인. (2011). 한국 농어업 - 농어촌유산 제도의 정립방안. 농어촌경관개 선종합대책추진계획(안). 농림수산식품부 지역개발과, 123.

\section{〈그림 2〉 국내외 유산관련제도의 체계화}

\subsection{3. 유산의 발굴 및 지정대상}

전통적 농어업 활동과 결과로서 나타난 농어업 및 농어촌의 장소나 마 을을 대상으로 한다. 인간은 끊임없이 환경의 혜택과 제약에 적응해 왔 고 다양한 형태로 경관과 생물환경을 형성해 왔으며, 여러 세대를 거치 면서 경험의 축적과 인간의 지식 체계를 심화시켜왔다. 농어업유산제도는 다른 제도와 달리 이러한 인간의 자연에 대한 적응적 과정을 강조한다.

문화재보호법에서 지정하고 있는 농어업 - 농어촌 유산과 관련된 문화 재의 지정방식이 외부적으로 나타난 물리적인 시설물 자체에 중점이 두 어지고, 그러한 시설이 생겨나기까지의 농어업활동이나 농어업활동을 주 
도하였던 농어민에 대한 시각이 결여되어 있다.

농어업유산제도는 $\mathrm{FAO}$ 의 경우와 같이 후보대상지역을 미리 받아서 심의를 거쳐서 파일럿 대상지역을 결정하는 두 개의 제도를 운영할 필요 가 있다.

유산발굴은 기존의 관련부처의 자원조사의 내용을 재검토하고, 나아가 서는 시장-군수의 신청을 받는 등의 다양한 상시적, 정기적인 발굴 및 신청절차를 활용할 수 있으며, 발굴된 유산은 농식품부가 운용하는 농어 업유산위원회가의 심의와 현지실사를 거친 후 등급 및 관리주체, 지원방 식 등에 대한 사항을 결정한다.

\subsection{4. 지방자치단체와 지역주민과의 협력체계 구축을 통한 구역지정}

농어업유산 구역은 두 가지 형태로 지정이 가능하다. 전통농어업과 관 련된 유산이 남아 있는 지구와 농촌마을을 대상으로 지정될 수 있으며, ‘농어업유산지구'와 '농어업유산마을'이라는 용어를 사용할 수 있다.

구역의 지정에 있어서 중장기적으로는 농촌이 보유한 자원의 특성이 잘 나타날 수 있도록 국토의 계획 및 이용에 관한 법률(이하 “국계법”)의 용도지구 및 농업 - 농촌관련법의 구역 등을 검토할 필요가 있다. 국계법 의 제 37 조는 용도지구의 하나로서 보존지구를 두고 있으나, 농어업유산 지구의 지정취지에 적합하게 재조정될 필요가 있다. 시·도지사가 조례 로 새로운 용도지구를 도시관리계획으로 결정할 수 있다는 규정을 두고 있어서, 농어업유산의 특성에 적합하게 농촌형의 보존지구를 생각해 볼 수 있으나, 현재까지는 사례가 없다는 면에서 시일이 소요될 것으로 보 인다.

구역의 지정에 있어서 단기적으로 중요하게 고려되어야 하는 요소는 기초자치단체 및 해당 지구에 살고 있는 주민의 의사이다. 기초자치단체 는 농어업유산의 보전 및 활용을 위한 재원 및 계획서의 작성과정에서 
역할을 하고, 지역의 주민은 자신들의 재산권과 직접적인 관련성을 맺을 뿐만 아니라, 실제로 지구를 지켜나가야 하는 활동의 주체가 될 수 있기 때문이다. 법률상의 지구지정 문제는 장기적으로 접근하고, 자치단체장 의 의사와 기여를 확인하고, 단기적으로는 주민과의 협약(주민협정)을 통하여 지구를 지정하고 지원을 통하여 관리해나가는 방향에서 검토가 필요하다.

농어업유산으로 지정하는 초기단계에서는 양보다는 질을 중시하여야 하고, 전 국민이 공감하고 사랑할 수 있는 대상 지구를 발굴하여 충분한 연구검토를 통하여 지정하는 것이 중요하다고 생각된다.

\subsection{5. 지역주민이 자발적으로 참여할 있는 지원 및 관리시스템의 구축}

농어업유산으로 지정된 경우, 유산의 성격에 따라서 규제와 지원제도 를 마련하되, 기본적으로 기존의 문화재에 대한 접근과는 다른 방식으로 규제하고 지원할 필요가 있다. 문화재 보호법에 의한 문화재가 지정으로 만 그치고, 규제중심임에 따라 지역의 발전에 활용되지 못하고 있는 점 을 감안하여, 농어업유산은 지역의 정체성을 대표할 수 있는 자원으로서 인식하고, 발굴과 보전을 전제로 지역의 발전에 기여할 수 있는 방안을 찾는 방향에서 규제와 지원제도를 병행하여 접근되는 것이 바람직하다. 농어업활동을 주도해온 농어민의 삶과 유리된 것이 아니라 농어민의 삶 을 존중하고, 농어민의 자발적인 참여와 계승이라는 차원에서 차별화될 필요가 있다. 규제와 지원을 균형적으로 고려하되, 주민이 보전작업에 자발적으로 참여할 수 있는 인센티브를 제공함으로써, 문화재청의 방식 과 차별화 모색이 필요하다.

농어업유산이 지역에서 고립되고 화석화되지 않고, 지역의 차별성과 지 역발전의 핵심자원으로서 인식하고, 이를 보전, 계승 및 이용할 수 있는 계획서의 수립을 의무화하고 중앙정부가 지정하는 농어업유산에 대하여는 
농식품부가 보전과 활용을 위한 계획수립비를 지원할 수 있어야 한다.

농촌개발에 있어서 주민의 참여가 매우 중요하다는 점을 감안하여, 지 역주민이 농어업유산을 스스로 계획하고, 활용하면서 관리해나갈 수 있 도록 주민 참여적 계획 및 시행을 유도하는 방안을 강구하고, 농어업유 산의 보전, 계승 및 유지활동을 위한 공동 활동경비를 지원할 필요가 있 다. 기본적으로 관리주체의 지정 및 지원은 마을 공동체를 대상으로 하 는 것을 원칙으로 하되, 관련 전문기관인 NPO 단체에게도 지원할 수 있 는 길을 열어두는 것이 바람직하다. 농어업유산에 대한 연구, 조사 및 보 고서의 작성과 농어업유산의 보전, 전승, 이용을 위한 계획수립, 주민활 동을 지원하고 나아가서는 세계농업유산으로의 지정 가능성 등에 대한 연구 등을 위한 전문 민간단체로서의 학회나 협회 등을 육성할 필요가 있다.

계획에 포함된 사업을 실제로 추진하고, 계획에 의한 농촌공간 관리를 정착시키기 위하여 계획과 예산의 연계를 강화시키는 방향으로 추진하는 것이 바람직하다. 기존 보조금 사업과는 별도의 농어업유산제도의 보존, 복원 및 전승을 위한 신규 보조금사업을 신설하는 것도 검토할 수 있다. 왜냐하면 농식품부가 지정·관리하는 농어업유산은 국가적인 차원에서 관리될 필요가 있다는 면에서 기존의 지방적 농촌개발사업과는 별도의 정책트랙으로 접근될 수도 있다.

\section{5. 결 론}

1960년대 이후 한국의 농촌개발역사는 경제성장과 근대화의 논리 속 에서 개발중심적인 사고와 행동의 틀 속에서 움직인 결과, 보전적 시각 에서 농촌공간을 바라보려는 실질적인 시도는 거의 없었다. 
현재의 농촌은 이미 원형이 상실된 채 국적 없는 개발이 이루어진 상 황에 놓여 있으며, 우리의 고유성과 정체성을 상실하고 있을 뿐만 아니 라, 우리의 국토공간을 어떤 방향으로 유도할 것인지에 방향성도 없는 것도 사실이다. 우리 국토는 우리의 새로운 미래를 창조할 수 있는 전통 적이고 고유성을 가진 유전인자까지도 상실할 수 있는 위기 상황에 직면 하고 있다.

농어업 - 농어촌 유산제도에 대한 정책도입에 대한 논의는 늦은 감이 있지만, 지금이라도 그동안의 개발일변도의 정책을 근본적으로 반성하 고, 농촌개발역사에 있어서 보전정책을 새롭게 시작하는 것은 매우 의미 있다. 새로운 보전정책의 구상은 보다 창의적이고 혁신적인 관점에서 접 근되기를 희망하고 우리의 고유성과 정체성에 대한 물음에서 시작하여 외국의 농촌공간과 차별화된 한국적인 농촌문화공간의 창출과 세계무역 자유화의 흐름 속에서 어려움에 직면하고 있는 농촌문제의 해결을 위한 새로운 성장동력의 발굴이라는 차원에서도 접근될 필요가 있다. 농촌정 책을 개발정책에서 보전정책으로의 전환은 범지구가 당면하고 있는 지구 온난화 등의 문제를 해결하는 데 요구되는 새로운 가치, 즉 생물다양성, 문화의 존중, 지속가능한 개발의 목표 가치를 지향하는 데 기여할 것으 로 생각된다.

농어업유산의 보전과 활용을 위한 제도도입은 기존의 정책과 중복되지 않고 차별성을 가질 수 있는 정책목표와 수단의 제시라는 관점에서 국내· 외의 관련 제도와 정책 환경의 변화를 감안하여 보다 구체적인 방안으로 고안되고 실천될 수 있어야 할 것이다. 


\section{- 참 고 문 헌}

김란기. (2005). 문화유산보호에 있어서 문화적 경관의 새로운 전개. 건축역사연구, 14(4), 288-304.

류재한. (2006). 문화자원을 통한 지역활성화 전략: 방데의 퓌뒤푸의 사례를 중심으 로, 한국 프랑스학 논집, 56, 339-354.

오민근. (2005). 문화적 경관개념의 도입과 보호체제. 국토 국토연구원, 92-108.

윤원근, \& 최식인. (2011). 한국 농어업·농어촌 유산발굴과 보전, 농업전망2012. 농촌경제연구원, 300-330.

윤원근, \& 최식인. (2011). 한국 농어업 - 농어촌유산 제도의 정립방안, 농어촌경관 개선종합대책추진계획(안). 농림수산식품부 지역개발과, 111-129.

윤원근, 최식인, 유학열, 조영재, \& 이인희. (2011). 청산도 구들장논의 분포와 물리 적 구조에 관한 연구. 한국농촌경제연구원.

이승구, \& 샤말레누카. (2008), 산악관광을 통한 지역개발 방향에 관한 연구-히말리 야 지역을 중심으로, 산학경영연구, 21(2).

황현탁 역. (1999). 문화경제학. 26.

최석호. (2006). 관광의 세계화: 유산관광개발한영비교사례연구. 관광학연구, 31(3), 29-50.

한숙영, \& 김사헌. (2007). 유산과 유산관광의 개념에 대하여. 관광학연구, 31(3), 209-223.

金田章裕. (2012). 文化的 景觀 27-88.

Huynh Hoa Thuy Tien. (2011), 베트남 호안 주민들의 관광개발 지각차이에 관한 연구. 세종대 국대대학원 석사논문.

Confer, J. C., \& kerstetter, D. L. (2000). Past perfect: Explorations of heritage. Tourism, Parks and Recreation, 35(2), 28-35.

Cemat. (2003). European Rural Heritage Guide.

Sacit Hadi Akdede, \& Emre Can. (2010). The Local Economic Effects of Istanbul Fener-Balat Cultural Heritage Rehabilitation Program. 재정정책론집, 12(1), 135 . 
http://www.wikipedia.org/.

http://www.fao.org/nr/giahs/.

http://whc.unesco.org/.

http//www.ramsar.org/.

http://www.cha.go.kr/

논문투고일: 2012. 4. 30

1차수정일: 2012. 5. 21

게재확정일: 2012. 6. 15

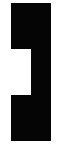

